\title{
Translating the biology of aging into novel therapeutics for Alzheimer disease
}

Yuko Hara, PhD, Nicholas McKeehan, BS, and Howard M. Fillit, MD

Neurology ${ }^{\circledR}$ 2019;92:84-93. doi:10.1212/WNL.0000000000006745
Correspondence

Dr. Fillit

hfillit@alzdiscovery.org

\begin{abstract}
Aging is the leading risk factor for most chronic illnesses of old age, including Alzheimer disease (AD), a progressive neurodegenerative disease with currently no therapies that prevent, slow, or halt disease progression. Like other chronic diseases of old age, the progressive pathology of $\mathrm{AD}$ begins decades before the onset of symptoms. Many decades of research in biological gerontology have revealed common processes that are relevant to understanding why the aging brain is vulnerable to $\mathrm{AD}$. In this review, we frame the development of novel therapeutics for $\mathrm{AD}$ in the context of biological gerontology. The many therapies currently in development based on biological gerontology principles provide promise for the development of a new generation of therapeutics to prevent and treat $\mathrm{AD}$.
\end{abstract}

\section{Introduction}

Advances in medicine, public health, and education have resulted in increased human lifespan, and the elderly population has grown dramatically worldwide. The increase in lifespan, however, has been accompanied by an increase in age-related chronic diseases, including type 2 diabetes mellitus, cardiovascular disease, cancer, osteoporosis, and neurodegenerative diseases. ${ }^{1}$ In fact, morbidity rates increase steadily to middle age, then increase at a much steeper rate such that it is twice as high in people over 80 compared to 60 - to 64-year-olds, a phenomenon related to the Gompertz curve. ${ }^{2}$

Geroscience is a multidisciplinary field that examines the relationship between biological aging and age-related diseases. ${ }^{3}$ The trans-NIH Geroscience Interest Group Summit discussed 7 processes that contribute to biological aging: macromolecular damage, epigenetic changes, inflammation, adaptation to stress, and impairments in proteostasis, stem cell regeneration, and metabolism. ${ }^{1}$ Intriguingly, these 7 processes are highly intertwined with one another. Thus, targeting the common biological processes of aging may be an effective approach to developing therapies to prevent or delay age-related diseases.

The leading risk factor for sporadic Alzheimer disease $(\mathrm{AD})$ is also aging. Processes that are altered with aging that have been implicated in $\mathrm{AD}$ include inflammation, impaired autophagy, mitochondrial dysfunction, vascular problems, epigenetic changes, and synaptic loss (figure). An increased incorporation of extensive knowledge regarding biological gerontology into research on $\mathrm{AD}$ would likely increase our productivity in developing new drugs for $\mathrm{AD}$. 


\section{Glossary}

$\mathbf{A} \beta=\beta$-amyloid $\mathbf{A D}=$ Alzheimer disease $;$ FDA $=$ Food and Drug Administration $;$ HDAC $=$ histone deacetylase IL $=$ interleukin; TUDCA $=$ tauroursodeoxycholic acid.

\section{Pathologic hallmarks of $\mathrm{AD}$}

Pathologic hallmarks of $\mathrm{AD}$ include senile plaques comprising $\beta$-amyloid $(A \beta)$ proteins along with many other misfolded proteins and neurofibrillary tangles formed by hyperphosphorylated tau protein aggregates. The accumulation of plaques and tangles occurs over many decades, in association with aging. While $A \beta$ can be detected in early adulthood even in cognitively healthy people, elevated amyloidosis begins in the 6th decade of life and increases linearly into old age. ${ }^{4}$ Medial temporal tauopathy also begins in middle age and overt cognitive impairment coincides with increased neurofibrillary tangle burden. ${ }^{5}$ Clearly, pathologic and clinical findings indicate that sporadic $\mathrm{AD}$ and related dementias are age-related diseases.
Although $A \beta$ plaques and neurofibrillary tangles are pathologic markers of $\mathrm{AD}$, it is not known if these pathologies represent valid drug targets or if these targets alone are sufficient to treat $\mathrm{AD}$. The current drug development pipeline strongly reflects focus on these 2 major pathologic proteins, with $32.5 \%$ of the currently ongoing $126 \mathrm{AD}$ clinical trials targeting either $\mathrm{A} \beta$ $(30 / 126,23.8 \%)$ or tau $(11 / 126,8.7 \%)$. Of phase 3 trials, $52 \%$ $(13 / 25)$ are pursuing these targets (12 targeting amyloid and 1 targeting tau). ${ }^{6}$ Therapeutic attempts to remove or decrease the production of $A \beta$ have appeared promising in preclinical and early-phase trials, but have been largely unsuccessful in altering the progression of $\mathrm{AD}$ in later-phase clinical trials. ${ }^{7}$

Because the mechanisms underlying $\mathrm{AD}$ and related dementias are complex and multifactorial, greater

Figure Age-related changes in biological processes contribute to neurodegeneration in Alzheimer disease (AD) and other dementias

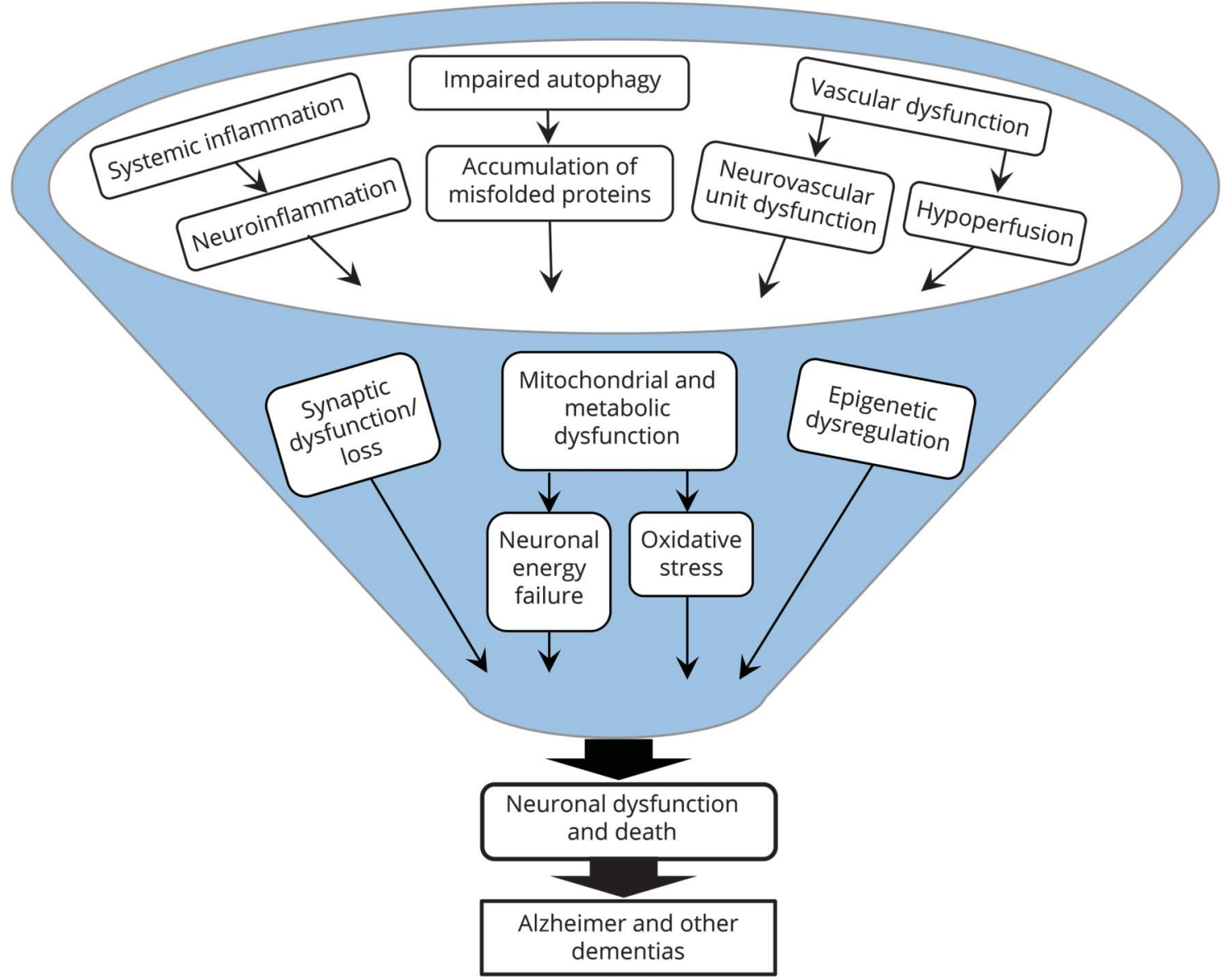

Processes that are altered with aging that precede neurodegeneration include inflammation, impaired autophagy, vascular dysfunction, synaptic loss, mitochondrial and metabolic dysfunctions, and epigenetic changes. These processes provide numerous novel targets for new drug development for AD. 
exploration of targets beyond these 2 pathologic markers is warranted.

\section{Inflammation}

Inflammation is a hallmark of aging. Inflammaging refers to the low-grade, chronic, systemic inflammation associated with aging in the absence of overt infection and is a significant risk factor for morbidity and mortality in the elderly. ${ }^{8}$ Furthermore, in middle-aged and older adults, higher levels of systemic inflammatory markers (e.g., C-reactive protein, interleukin [IL]-6, fibrinogen) are associated with cortical thinning, ${ }^{9}$ lower and greater declines in regional cerebral blood flow, ${ }^{10}$ and poorer cognitive functions, including executive function and learning and memory. ${ }^{11}$ However, randomized clinical trials of broad-spectrum anti-inflammatory drugs such as nonsteroidal anti-inflammatory drugs (e.g., naproxen, aspirin, celecoxib) and others (e.g., prednisone, statins, rosiglitazone) have thus far failed to improve cognitive outcomes in patients with $\mathrm{AD} .{ }^{12}$ Currently, there are 12 ongoing clinical trials testing anti-inflammatory interventions (table 1), 7 of which are repurposed drugs (e.g., antiviral, antibiotic, and rheumatoid arthritis medications) and 1 is a biologic (plasma). ${ }^{6}$

It is worth emphasizing a few recent efforts that target specific aspects of inflammation. For example, GC021109, which was shown to be safe in a phase 1 trial of patients with $\mathrm{AD}$, promotes microglial phagocytosis by binding to the microglial P2Y6 receptor. ${ }^{13,14}$ Other approaches attempt to reduce microglial cytokine production. The NLRP3 inflammasome is a multiprotein complex involved with the innate immune system and activates procaspase-1, which in turn induces production of proinflammatory cytokines $\mathrm{IL}-1 \beta$ and $\mathrm{IL}-18 .^{8}$ The NLRP3 inflammasome significantly contributes to neuroinflammation and age-related cognitive decline and is potently activated by $A \beta .{ }^{15}$ Novel compounds that specifically inhibit the NLRP3 inflammasome are currently under development, with companies such as IFM Therapeutics (Boston, MA) expecting to have NLRP3 inhibitors for AD in clinical studies by 2020 (ifmthera. $\mathrm{com} /$ pipeline/). Resolution is the final stage of the inflammatory response when immune cells, apoptotic cells, and debris are cleared from the site of insult and proinflammatory mediators are catabolized such that the tissue can reach functional homeostasis. ${ }^{16}$ With chronic inflammation, there is incomplete resolution of the initial response, resulting in chronic and increased levels of tumor necrosis factors, interferons, and IL-6. Instead of globally inhibiting inflammation, it may be fruitful to promote resolution of inflammation by using specialized proresolving mediators. ${ }^{17}$

Senescent cells are thought to fuel aging and age-related pathologies as they release proinflammatory cytokines, chemokines, and tissue-damaging proteases and can negatively affect the surrounding tissue microenvironment. ${ }^{18}$ Senolytic drugs are drawing attention as they selectively induce apoptosis of these senescent cells. While senolytic drugs appear to provide beneficial effects in rodent models of aging, they may also be associated with slowed wound healing. ${ }^{19}$ Further work is needed to establish a causal link between senescent cell accumulation and $\mathrm{AD}$ before these drugs can be translated into the clinic. In addition, drugs targeting specific phenotypes of myeloid cells or select elements of the complement pathway are in preclinical and clinical development. ${ }^{20,21}$ It is critical that these agents inhibit the detrimental aspects of inflammation while preserving the defense mechanisms against pathogens and tissue damage and allowing for continued phagocytosis by microglia.

Table 1 Interventions targeting inflammation that are in clinical development for Alzheimer disease (as of July 1, 2017 ${ }^{6}$ )

\begin{tabular}{llll}
\hline Intervention & Mechanism of action & Phase & Sponsor \\
\hline ALZT-OP1 & Cromolyn sodium + ibuprofen & Phase 3 & $\begin{array}{l}\text { AZTherapies, Inc., PharmaConsulting Group, } \\
\text { KCAS Bio, APCER Life Sciences }\end{array}$ \\
\hline Azeliragon & RAGE inhibitor & Phase 3 & VTv Therapeutics \\
\hline CSP-1103 & Microglia activator & Phase 2 & CereSpir \\
\hline Etanercept & Tumor necrosis factor-a inhibitor & Phase 2 & University of Southampton \\
\hline GC021109 & P2Y6 agonist & Phase 1 & GliaCure, Inc. \\
\hline Masitinib & Tyrosine kinase inhibitor & Phase 3 & AB Science \\
\hline Minocycline & Tetracycline antibiotic & Phase 2 & King's College London \\
\hline NP001 & $\begin{array}{l}\text { Sodium chlorite; regulator of inflammatory } \\
\text { monocytes/macrophages }\end{array}$ & Phase 1 & Neuraltus Pharmaceuticals, Inc. \\
\hline Plasma & Nonspecific & Phase 1 & Stanford University, Alkahest, Inc. \\
\hline Sargramostim & Granulocyte colony stimulator & Phase 2 & University of Colorado, Denver, The Dana Foundation \\
\hline Valaciclovir & Antiviral & Phase 2 & Hugo Lovheim, Umeå University \\
\hline VX-745 & p38 mitogen-activated protein kinase inhibitor & Phase 2 & EIP Pharma, LLC \\
\hline
\end{tabular}




\section{Impairment in autophagy and clearance of misfolded proteins}

Autophagy is a process that involves the degradation and recycling of damaged/aggregated proteins, lipids, and larger cellular components including organelles. Autophagic activity decreases with aging, and genes that promote autophagy have been associated with increased lifespan in model organisms. ${ }^{22}$ In $\mathrm{AD}$ models, impaired autophagy is tightly linked to the accumulation of plaques and tangles. Since $A \beta$ and tau are not the only proteins that misfold or form toxic aggregates in the aging brain, broadly promoting or restoring the impaired autophagic mechanisms may be a more parsimonious way to prevent accumulations of the many various damaged proteins that occur with aging. ${ }^{23}$ Nilotinib, a Food and Drug Administration (FDA)-approved drug for the treatment of adult chronic myeloid leukemia, is currently being tested in a phase 2 trial in $\mathrm{AD} .{ }^{24}$ Nilotinib boosts the autophagic machinery by increasing levels of parkin, which is an E3 ubiquitin ligase that plays a critical role in ubiquitination and clearance of misfolded and damaged proteins. ${ }^{25}$ Perhaps the greatest challenge in restoring clearance mechanisms is to concurrently promote each stage of its machinery, from autophagosome biogenesis, lysosomal fusion, to the final degradation of cargos within autolysosomes. ${ }^{26}$ This is important because simply inducing autophagy would lead to accumulation of autophagosomes and undigested autolysosomes, which can block axonal trafficking and lead to axonal swelling. A combination of drugs may be necessary in restoring this autophagic flux. Additional challenges include off-target effects of agents that promote autophagy as well as the lack of validated assays to measure autophagic flux in humans. ${ }^{22}$

\section{Mitochondrial and metabolic dysfunctions}

The free radical theory of aging, the idea that free radicals produced in the course of cellular metabolism contribute to aging and degenerative diseases, was first introduced in 1956 by Harman. ${ }^{27}$ Indeed, mitochondrial dysfunction and oxidative stress increase with aging and are tightly linked to neurodegeneration. High metabolic demands along with low levels of antioxidative defense mechanisms make the brain especially vulnerable to oxidative damage. ${ }^{28}$ Aging and $\mathrm{AD}$ are associated with inefficient mitochondria and an imbalance between pro-oxidants and antioxidants, which in turn, induce oxidative damage to DNA, proteins, and lipids in the brain. To date, antioxidant agents have not been successful in treating $\mathrm{AD},{ }^{29}$ partly due to their low bioavailability and poor blood-brain barrier penetration. They may also block oxidative signaling that is necessary for normal cellular functioning.

There are 14 interventions targeting mitochondrial or metabolic dysfunctions that are currently in clinical trials for $\mathrm{AD}$ (table 2). ${ }^{6}$ Many of these are repurposed drugs and 7 are antidiabetics. Type 2 diabetes mellitus is a significant risk factor for $\mathrm{AD}$ and both diseases share pathologies including insulin resistance and oxidative stress. ${ }^{30}$ Thus, insulin, its derivatives, and drugs designed to improve insulin sensitivity such as liraglutide and exenatide are currently being tested for $\mathrm{AD}$ (table 2).

Agents that specifically target mitochondria to decrease mitochondria-derived reactive oxygen species may also hold promise for preventing neuronal dysfunction and death. For example, CP2 is a cell-permeable tricyclic pyrone that crosses the blood-brain barrier and accumulates in neuronal mitochondria. ${ }^{31}$ It mildly inhibits the mitochondrial complex I, producing a mito-hormetic effect, augmenting respiratory capacity and reducing proton leak in wild-type mice. $\mathrm{CP} 2$ also prevents cognitive impairment in mouse models of AD (APP, PS1, and APP/ PS1) while reducing amyloid plaques and phosphorylated tau. SS-31 is another example of a compound with mitochondriaspecific actions. It is a small peptide that binds to cardiolipin, a lipid exclusively expressed on the inner mitochondrial membrane that plays a structural role in organizing the components of the electron transport chain into supercomplexes for more efficient oxidative phosphorylation. ${ }^{32,33}$ SS-31 also inhibits the opening of the mitochondrial permeability transition pore that forms under mitochondrial stress, which can lead to mitochondrial swelling and apoptosis. ${ }^{34}$ Preclinical studies have shown that SS-31 prevents anesthesia-induced cognitive impairment and promotes mitochondrial and synaptic health in models of $\mathrm{AD}^{34,35}$ SS-31 (elamipretide) is currently being tested in clinical trials for rare disease indications, including mitochondrial myopathy, Barth syndrome, Leber hereditary optic neuropathy, and Huntington disease (stealthbt.com/clinical). A repurposing opportunity for SS-31 exists for $\mathrm{AD}$.

\section{Vascular dysfunction}

Aging is associated with vascular disease, which contributes to vascular cognitive impairment, vascular dementia, and other dementias including $\mathrm{AD}$. Studies have shown that the total burden of vascular pathology correlates with cognitive deficits, ${ }^{36}$ and $79.9 \%$ of people with $\mathrm{AD}$ were reported to have vascular pathology at autopsy. ${ }^{37}$ The brain requires continuous and well-regulated blood flow due to the high energy demand and inability to store energy. Vascular impairment can result in hypoperfusion, dysfunction of the neurovascular unit, oxidative stress, or inflammation, which in turn can lead to endothelial damage, small vessel disease, blood-brain barrier breakdown, demyelination, infarcts, hemorrhages, and cerebral atrophy. ${ }^{38}$ There are currently 11 clinical trials testing interventions that target the vascular system (table 3), of which 9 are repurposed drugs such as antihypertensives and antihyperlipidemic agents and 2 are omega-3 fatty acids. ${ }^{6}$

While managing vascular risk factors such as hypertension, dyslipidemia, and diabetes is likely to improve long-term brain health and lower dementia risk, additional efforts to target 
Table 2 Interventions targeting mitochondrial and metabolic dysfunctions that are in clinical development for Alzheimer disease (as of July 1, 20176)

\begin{tabular}{|c|c|c|c|}
\hline Intervention & $\begin{array}{l}\text { Mechanism of } \\
\text { action }\end{array}$ & Phase & Sponsor \\
\hline AC-1204 & $\begin{array}{l}\text { Tricaprilin; } \\
\text { ketogenic }\end{array}$ & Phase 3 & Accera, Inc. \\
\hline Benfotiamine & $\begin{array}{l}\text { Vitamin B1 } \\
\text { derivative }\end{array}$ & Phase 2 & $\begin{array}{l}\text { Burke Medical Research Institute, Burke Rehabilitation Hospital, Columbia University, } \\
\text { National Institute on Aging, Alzheimer's Drug Discovery Foundation }\end{array}$ \\
\hline Exendin-4 & $\begin{array}{l}\text { GLP-1 receptor } \\
\text { agonist }\end{array}$ & Phase 2 & National Institute on Aging, NIH Clinical Center \\
\hline $\begin{array}{l}\text { Grape seed polyphenolic } \\
\text { extract, resveratrol }\end{array}$ & Antioxidant & Phase 1 & Johns Hopkins University, Icahn School of Medicine at Mount Sinai \\
\hline Insulin aspart & $\begin{array}{l}\text { Increased insulin } \\
\text { signaling }\end{array}$ & Phase 1 & Wake Forest School of Medicine, National Institute on Aging, General Electric \\
\hline Insulin detemir & $\begin{array}{l}\text { Increased insulin } \\
\text { signaling }\end{array}$ & Phase 2 & Wake Forest School of Medicine, Alzheimer's Association \\
\hline Insulin glulisine & $\begin{array}{l}\text { Increased insulin } \\
\text { signaling }\end{array}$ & Phase 2 & HealthPartners Institute for Education and Research \\
\hline Insulin (Humulin R U-100) & $\begin{array}{l}\text { Increased insulin } \\
\text { signaling }\end{array}$ & Phase 3 & $\begin{array}{l}\text { University of Southern California, National Institute on Aging, Alzheimer's } \\
\text { Therapeutic Research Institute, Wake Forest School of Medicine }\end{array}$ \\
\hline Liraglutide & $\begin{array}{l}\text { GLP-1 receptor } \\
\text { agonist }\end{array}$ & Phase 2 & $\begin{array}{l}\text { Imperial College London, King's College Hospital NHS Trust, University of } \\
\text { Oxford, University of Southampton, Avon and Wiltshire Mental Health Partnership NHS } \\
\text { Trust }\end{array}$ \\
\hline MSDC-0160 & $\begin{array}{l}\text { mTOT modulator, } \\
\text { insulin sensitizer }\end{array}$ & Phase 2 & Metabolic Solutions Development Company \\
\hline Nicotinamide & Vitamin B3 & Phase 2 & University of California, Irvine \\
\hline Oxaloacetate & $\begin{array}{l}\text { Intermediate of the } \\
\text { Krebs cycle }\end{array}$ & Phase 1 & Russell Swerdlow, MD, University of Kansas Medical Center \\
\hline Pioglitazone & PPAR- $\gamma$ agonist & Phase 3 & Takeda Pharmaceutical Company, Zinfandel Pharmaceuticals Inc. \\
\hline T3D-959 & PPAR- $\delta / \gamma$ agonist & Phase 2 & T3D Therapeutics, Inc. \\
\hline
\end{tabular}

specific vascular pathobiologies are needed. For example, upon blood-brain barrier disruption or vascular breakdown, fibrinogen leaks into the CNS, resulting in formation of clots comprising insoluble fibrin and inflammation. ${ }^{39}$ Extravascular fibrin(ogen) then interacts with microglia via the integrin receptor CD11b/CD18, which induces secretion of cytokines and chemokines and stimulates recruitment of peripheral monocytes and macrophages. ${ }^{40}$ While fibrinogen is undetectable in the healthy brain, it is present in the brains of patients with $\mathrm{AD}$ as well as in older people without $\mathrm{AD}$ pathology. ${ }^{41,42} \mathrm{~A} \beta$ also interacts with fibrinogen and coagulation factor XII, which can further increase clotting, fibrin deposition, and proinflammatory molecules. ${ }^{43}$ Therefore, a higher plasma level of fibrinogen is associated with an increased risk for $\mathrm{AD}$ and vascular dementia. ${ }^{44}$ Thrombin, an enzyme in blood plasma that causes blood clotting by converting fibrinogen to fibrin, is also elevated in the brains of patients with $\mathrm{AD}$, and produces proinflammatory effects on endothelial cells, microglia, and astrocytes. ${ }^{45}$ Targeting the coagulation system may reduce fibrin formation, neuroinflammation, and neurodegeneration; however, it is important to specifically target the pathogenic properties of coagulation proteins without affecting the beneficial processes of blood clotting.

\section{Epigenetic changes}

Aging is also accompanied by important epigenetic changes including histone modifications, DNA methylation, and microRNA expression, resulting in alterations in gene expression and genome architecture. ${ }^{46}$ As epigenetic mechanisms are critical for normal brain function, including learning and memory processes, epigenetic dysregulations may contribute to the onset of cognitive dysfunction and $\mathrm{AD} .{ }^{47}$ Because ageand disease-related epigenetic disturbances are potentially reversible, they have drawn attention as attractive targets for pharmacologic interventions particularly in cancer therapies, but they are also gaining traction in neurodegenerative diseases. There are a few epigenetic drugs currently being tested in clinical trials for $\mathrm{AD}$. Vorinostat, a pan-histone deacetylase (HDAC) inhibitor approved for the treatment of cutaneous T-cell lymphoma, is currently in phase I trial in patients with $\mathrm{AD} .^{48}$ ORY-2001 is a selective dual LSD1-MAO-B inhibitor that has shown marked cognitive improvement in transgenic $\mathrm{AD}$ models, and phase I results showed safety, tolerability, and brain penetrance. ${ }^{49}$ LSD1 is an epigenetic modulator that regulates histone methylation. The major advantage of epigenetic drugs is that they can regulate expression of multiple 
Table 3 Interventions targeting vascular dysfunctions that are in clinical development for Alzheimer disease (as of July 1 , $2017^{6}$ )

\begin{tabular}{|c|c|c|c|}
\hline Intervention & Mechanism of action & Phase & Sponsor \\
\hline Candesartan & Angiotensin receptor blocker & Phase 2 & Emory University \\
\hline Cilostazol & Phosphodiesterase 3 antagonist & Phase 2 & National Cerebral and Cardiovascular Center, Japan \\
\hline Gemfibrozil & Modulation of microRNA pathways & Phase 1 & Gregory Jicha, University of Kentucky \\
\hline Icosapent ethyl & $\begin{array}{l}\text { Eicosapentaenoic acid, a type of omega- } \\
3 \text { fatty acid }\end{array}$ & Phase 3 & $\begin{array}{l}\text { VA Office of Research and Development, University of Wisconsin, } \\
\text { Madison }\end{array}$ \\
\hline Nilvadipine & Calcium channel blocker & Phase 3 & $\begin{array}{l}\text { University of Dublin, Trinity College, Molecular Medicine Ireland LBG, } \\
\text { Alzheimer Europe, Archer Pharmaceuticals, Inc., E-Search Limited, } \\
\text { University College Dublin, GABO:mi, King's College London, Istituto Di } \\
\text { Ricerche Farmacologiche Mario Negri, University Hospital, Lille, } \\
\text { University of Ulm, Szeged University, Goeteborgs Universitet, University } \\
\text { College Cork, Aristotle University of Thessaloniki, Stichting Katholieke } \\
\text { Universiteit }\end{array}$ \\
\hline
\end{tabular}

\begin{tabular}{|c|c|c|c|}
\hline Omega-3 PUFA & $\begin{array}{l}\text { Decrease triglycerides, reduce blood } \\
\text { clotting }\end{array}$ & Phase 2 & Oregon Health and Science University, National Institute on Aging \\
\hline Simvastatin & HMG-CoA reductase inhibitor (statin) & Phase 2 & University of Wisconsin, Madison, National Institute on Aging \\
\hline $\begin{array}{l}\text { Simvastatin, L- } \\
\text { arginine, } \\
\text { tetrahydrobiopterin }\end{array}$ & $\begin{array}{l}\text { HMG-CoA reductase inhibitor and } \\
\text { antioxidant }\end{array}$ & Phase 2 & University of Massachusetts, Worcester \\
\hline Tadalafil & PDE5 inhibitor; increases blood flow & Phase 2 & $\begin{array}{l}\text { St. George's, University of London, Alzheimer's Drug Discovery } \\
\text { Foundation, Alzheimer's Society UK, University of Copenhagen, } \\
\text { University of Glasgow, St George's University Hospitals NHS Foundation } \\
\text { Trust }\end{array}$ \\
\hline Telmisartan & Angiotensin 2 receptor antagonist & Phase 1 & Emory University \\
\hline $\begin{array}{l}\text { Telmisartan, } \\
\text { perindopril }\end{array}$ & $\begin{array}{l}\text { Angiotensin } 2 \text { receptor antagonist } \\
\text { (Telmisartan) and ACE inhibitor } \\
\text { (Perindopril) }\end{array}$ & Phase 2 & $\begin{array}{l}\text { Alzheimer's Drug Discovery Foundation, Sunnybrook Health Sciences } \\
\text { Centre }\end{array}$ \\
\hline
\end{tabular}

genes critical for neuronal functions. However, studies are required to confirm that these drugs aimed to counter neurodegeneration in the brain do not also increase gene expression associated with harm, such as tumorigenesis. Preclinical efforts addressing these safety issues are also underway, including selective inhibitors of HDAC2 that show functional efficacy and reduced side effects in animal models (rodintherapeutics.com/ our-approach/\#literature).

\section{Synaptic loss and dysfunction}

Normal age-related cognitive decline is not accompanied by the extensive neuronal loss seen in $\mathrm{AD}$ and other dementias; however, it is associated with dysfunctions and loss of cortical synapses. ${ }^{50}$ These synaptic alterations occur in the same circuits that degenerate in $\mathrm{AD}$. Based on a postmortem study, synapse loss is observed in a large proportion of people with mild cognitive impairment and appears to be an early event in the disease process that precedes neuronal loss in $\mathrm{AD} .^{51}$ Because agerelated synaptic alterations may render neurons more vulnerable to degeneration, maintaining synaptic health in the face of aging may be an important strategy for preventing neurodegeneration.

There is growing interest in therapies that promote neuronal and synaptic health for preventing and treating dementia.
Currently 19 neuroprotective interventions are being tested in clinical trials for $\mathrm{AD}$ (table 4 ), of which 5 are cell therapies (e.g., stem cells), 3 are natural products, and 2 are biologics. ${ }^{6}$ In particular, nerve growth factor signaling has drawn interest as a potential neuroprotective target for $\mathrm{AD}$. LM11A31-BHS, a small molecule ligand for the p 75 neurotrophin receptor $\left(\mathrm{p} 75^{\mathrm{NTR}}\right)$, is currently being tested in a phase 2 trial in patients with $\mathrm{AD}$. Treatment with this molecule reversed cholinergic neurite degeneration in $\mathrm{AD}$ mouse models even when it was initiated after significant pathology was already present. $^{52}$

\section{Combination therapies}

As discussed above, multiple processes go awry with aging, many of which negatively affect neuronal and cognitive health and ultimately contribute to the onset and progression of $\mathrm{AD}$. Therefore, a combination of drugs to address these systems may be necessary to effectively treat it. There are currently 11 combination therapy clinical trials (table 5), of which 5 are testing an add-on therapy to an already approved $\mathrm{AD}$ drug (e.g., donepezil), and several others are using multiple drugs to target $\mathrm{A} \beta .^{6}$ In 2018, a phase 2 clinical trial to test AMX0035, a combination of sodium phenylbutyrate and tauroursodeoxycholic acid (TUDCA), is expected to begin. 
Table 4 Neuroprotective interventions that are in clinical development for Alzheimer disease (as of July 1, 20176)

\begin{tabular}{|c|c|c|c|}
\hline Intervention & Mechanism of action & Phase & Sponsor \\
\hline $\begin{array}{l}\text { Adipose-derived } \\
\text { stromal cells }\end{array}$ & Nonspecific & Phase 2 & Ageless Regenerative Institute \\
\hline Allopregnanolone & GABA-A receptor modulator & Phase 1 & University of Southern California, National Institute on Aging \\
\hline ANAVEX2-73 & $\begin{array}{l}\text { Sigma1/muscarinic receptor } \\
\text { agonist }\end{array}$ & Phase 2 & Anavex Life Sciences Corp. \\
\hline AstroStem & $\begin{array}{l}\text { Autologous fat stem cells; } \\
\text { nonspecific }\end{array}$ & Phase 2 & Nature Cell Co. Ltd. \\
\hline AZD0530 & Src tyrosine kinase inhibitor & Phase 2 & Yale University, Alzheimer's Therapeutic Research Institute \\
\hline Bryostatin 1 & Protein kinase $\mathrm{C}$ modulator & Phase 2 & Neurotrope Bioscience, Inc. \\
\hline CB-AC-02 & $\begin{array}{l}\text { Placenta-derived } \\
\text { mesenchymal stem cells; } \\
\text { nonspecific }\end{array}$ & Phase 2 & CHABiotech Co., Ltd. \\
\hline CT1812 & Sigma2 receptor antagonist & Phase 2 & Cognition Therapeutics \\
\hline GV1001 & $\begin{array}{l}\text { Telomerase reverse } \\
\text { transcriptase vaccine }\end{array}$ & Phase 2 & GemVax \& Kael \\
\hline L-Serine & Amino acid & Phase 2 & $\begin{array}{l}\text { Dartmouth-Hitchcock Medical Center, Brain Chemistry Laboratories, Institute for } \\
\text { Ethnomedicine }\end{array}$ \\
\hline LM11A-31 & $\begin{array}{l}\text { p75 neurotrophin receptor } \\
\text { agonist }\end{array}$ & Phase 2 & PharmatrophiX \\
\hline $\begin{array}{l}\text { Mesenchymal stem } \\
\text { cells (allogenic) }\end{array}$ & Nonspecific & Phase 2 & Stemedica Cell Technologies, Inc., Stemedica International SA \\
\hline $\begin{array}{l}\text { Mesenchymal stem } \\
\text { cells (umbilical cord) }\end{array}$ & Nonspecific & Phase 2 & $\begin{array}{l}\text { South China Research Center for Stem Cell and Regenerative Medicine, Third } \\
\text { Affiliated Hospital, Sun Yat-Sen University, Sun Yat-Sen Memorial Hospital of Sun } \\
\text { Yat-Sen University, Guangzhou Psychiatric Hospital }\end{array}$ \\
\hline MLC901 & $\begin{array}{l}\text { Ingredients from natural } \\
\text { products; nonspecific }\end{array}$ & Phase 2 & National University Hospital, Singapore \\
\hline Rasagiline & $\begin{array}{l}\text { Monoamine oxidase B } \\
\text { inhibitor }\end{array}$ & Phase 2 & The Cleveland Clinic \\
\hline S-Equol & Estrogen receptor $\beta$ agonist & Phase 2 & $\begin{array}{l}\text { Russell Swerdlow, MD, Ausio Pharmaceuticals, LLC, University of Kansas Medical } \\
\text { Center }\end{array}$ \\
\hline STA-1, donepezil & Antioxidant (echinacoside) & Phase 2 & Sinphar Pharmaceutical Co., Ltd. \\
\hline T-817 MA & $\begin{array}{l}\text { Sigma receptor activator, } \\
\text { neurotrophic }\end{array}$ & Phase 2 & Toyama Chemical Co., Ltd., Alzheimer's Disease Cooperative Study \\
\hline Xanamem & $\begin{array}{l}\text { 11-HSD1 enzyme activity } \\
\text { blocker }\end{array}$ & Phase 2 & Actinogen Medical, ICON Clinical Research \\
\hline
\end{tabular}

Sodium phenylbutyrate is an FDA-approved therapy for urea cycle disorders and it is a Class I and II HDAC inhibitor. Preclinical studies have shown that it also acts as a chemical chaperone and ameliorates ER stress, prevents neuronal loss, increases clearance of intraneuronal $A \beta$, and restores cognitive functions in $\mathrm{AD}$ mouse models. ${ }^{53-55}$ TUDCA is a bile acid that supports mitochondrial energetics by reducing mitochondrial permeability and increasing apoptotic thresholds of cells. ${ }^{56}$ Studies in an $\mathrm{AD}$ mouse model (APP/PS1) have shown that TUDCA decreases A $\beta$ deposits, reduces glial activation, and restores cognitive functions. ${ }^{57,58}$ Together, the 2 drugs are designed to restore epigenetic changes, reduce cellular stress, and protect against neurodegeneration, mitochondrial dysfunction, and neuroinflammation.
Combination trials present some challenges as each drug needs to be tested for safety, and multiple biomarkers are often required to ensure target engagement and to monitor disease progression and response to treatment. Some evidence of efficacy should be demonstrated for each drug, though benefits of each may be incremental. Combination therapies that target multiple age-related dysfunctions with synergistic activities are especially promising for treating $\mathrm{AD}$. More such combination studies are needed.

\section{Future directions}

Biological aging is the leading risk factor for the major debilitating chronic diseases of old age that cause morbidity and 
mortality, including $\mathrm{AD}$ and other dementias. Drugs that treat fundamental biological mechanisms of aging have been proposed to be useful for most prevalent chronic diseases of aging. ${ }^{18}$ In fact, many repurposed drugs are used to treat other age-related diseases. Despite over 75 years of accumulated research on biological aging, ${ }^{59}$ the current drug development pipeline is dominated by therapeutics targeting $A \beta$ and tau, and there has been proportionately less translation of biological gerontology into our efforts to develop drugs for $\mathrm{AD}$. Nevertheless, aging biology provides numerous novel targets for new drug development for $\mathrm{AD}$ (figure).

Because of the multifaceted nature of biological aging, it is unlikely that drugs addressing a single target will be very successful in effectively treating AD. Nevertheless, single drug clinical trials may be needed to demonstrate incremental benefits, even if modest, before combination trials can be pursued. As interventions that target one aberrant system tend to also attenuate others, ultimately, combination therapies that target multiple age-related dysfunctions may produce synergistic activities. Combination therapies are already the standard of care for other diseases of aging, including heart disease, cancers, and hypertension, and will likely be necessary in treating $\mathrm{AD}$ and other dementias. And because the same biological aging mechanisms underpin the common diseases of aging, repurposing drugs already on the market is a rational strategy for testing new therapies for $\mathrm{AD}$ and related dementias, including the sporadic forms of frontotemporal dementia and vascular dementia. Novel therapeutics for new and relevant targets will clearly also be needed.

In addition to combination therapies, addressing the multifaceted nature of the relationship between biological aging and $\mathrm{AD}$ with drugs possessing pleiotropic effects (simultaneously producing more than one effect) will be advantageous. In clinical areas such as oncology, psychiatry, and cardiovascular medicine, many effective drugs act on multiple targets while singletargeted approaches seldom progress to the final stages of clinical trials. ${ }^{60}$ For example, statins are widely used to lower cholesterol levels in patients with dyslipidemia, but statins also have pleiotropic effects that are independent of their effects on cholesterol, including improved endothelial function, inhibition of vascular inflammation, stabilization of atherosclerotic plaques, and immunomodulation. ${ }^{60}$ To effectively treat $\mathrm{AD}$, pleiotropic drugs may need to hit the right nodes of relevant biological networks affected by aging such that they positively influence those networks and interconnected pathways.

Finally, a parsimonious approach to drug discovery and development with regard to translating knowledge from biological aging to $\mathrm{AD}$ is needed. For example, due to the plethora of misfolded proteins that accumulate with aging in the brain,

Table 5 Combination therapies that are in clinical development for Alzheimer disease (as of July 1, 2017 ${ }^{6}$ )

\begin{tabular}{|c|c|c|c|}
\hline Intervention & Mechanism of action & Phase & Sponsor \\
\hline ALZT-OP1 & Cromolyn sodium + ibuprofen & Phase 3 & $\begin{array}{l}\text { AZTherapies, Inc., PharmaConsulting Group, KCAS Bio, } \\
\text { APCER Life Sciences }\end{array}$ \\
\hline CNP520, CAD106 & BACE1 inhibitor + anti-amyloid antibody & Phase 3 & $\begin{array}{l}\text { Novartis Pharmaceuticals, Banner Alzheimer's Institute, } \\
\text { National Institute on Aging, Alzheimer's Association, Amgen }\end{array}$ \\
\hline CPC-201 & $\begin{array}{l}\text { Donepezil (acetylcholinesterase inhibitor) + } \\
\text { a peripherally acting cholinergic blocker }\end{array}$ & Phase 2 & Chase Pharmaceuticals Corporation \\
\hline DHP1401, donepezil & $\begin{array}{l}\text { AMPA receptor and MAP kinase modulation + } \\
\text { donepezil }\end{array}$ & Phase 2 & Daehwa Pharmaceutical Co., Ltd. \\
\hline $\begin{array}{l}\text { Gantenerumab, } \\
\text { solanezumab }\end{array}$ & $\begin{array}{l}\text { Antibody against } A \beta \text { fibrils + antibody against soluble } \\
\text { monomeric } A \beta\end{array}$ & Phase 3 & $\begin{array}{l}\text { Washington University School of Medicine, Eli Lilly and } \\
\text { Company, Hoffmann-La Roche, Alzheimer's Association, } \\
\text { National Institute on Aging, Avid Radiopharmaceuticals, } \\
\text { Accelerating Medicines Partnership }\end{array}$ \\
\hline $\begin{array}{l}\text { Grape seed } \\
\text { polyphenolic } \\
\text { extract, resveratrol }\end{array}$ & Antioxidant & Phase 1 & $\begin{array}{l}\text { Johns Hopkins University, Icahn School of Medicine at Mount } \\
\text { Sinai }\end{array}$ \\
\hline $\begin{array}{l}\text { Lu AE58054, } \\
\text { memantine }\end{array}$ & $\begin{array}{l}\text { 5-HT6 receptor antagonist + memantine (NMDA } \\
\text { receptor blocker) }\end{array}$ & Phase 3 & H. Lundbeck A/S, Otsuka Pharmaceutical \\
\hline РXT00864 & $\begin{array}{l}\text { Acamprosate (NMDA receptor antagonist/positive } \\
\text { allosteric modulator of GABA-A receptors) + baclofen } \\
\text { (GABA-B receptor agonist) }\end{array}$ & Phase 2 & Pharnext SA, Ascopharm Groupe Novasco \\
\hline $\begin{array}{l}\text { Simvastatin, } \\
\text { L-arginine, } \\
\text { tetrahydrobiopterin }\end{array}$ & HMG-CoA reductase inhibitor and antioxidant & Phase 2 & University of Massachusetts, Worcester \\
\hline STA-1, donepezil & Antioxidant (echinacoside) + donepezil & Phase 2 & Sinphar Pharmaceutical Co., Ltd. \\
\hline TAK-071, donepezil & $\begin{array}{l}\text { Muscarinic M1R positive allosteric modulator + } \\
\text { donepezil }\end{array}$ & Phase 1 & Takeda Pharmaceutical Co., Ltd. \\
\hline
\end{tabular}


biologics that attempt to address a single misfolded protein may be far less efficacious than drugs that enhance autophagy and clearance of all misfolded proteins. Similarly, age-related inflammation, vascular disease, epigenetic dysregulation, mitochondrial/metabolic dysfunction, and synaptic failure may be upstream causes of neuronal dysfunction and death leading to the classic pathologic hallmarks that have been historically among the first drug targets in $\mathrm{AD}$. A better understanding and translation of the systemic, cellular, and molecular processes of biological aging that precede and increase vulnerability to $\mathrm{AD}$ will help identify new strategies and therapeutic targets for drug discovery and development.

\section{Study funding}

This work was supported by a donation to the Alzheimer's Drug Discovery Foundation by an anonymous foundation. Alzheimer's Drug Discovery Foundation has funded or cofunded several projects to develop or clinically test the following drugs that are discussed in the article: nilotinib, CP2, GC021109, LM11A-31, and ORY-2001.

\section{Disclosure}

The authors report no disclosures relevant to the manuscript. Go to Neurology.org/N for full disclosures.

\section{Publication history}

Received by Neurology June 14, 2018. Accepted in final form August 23, 2018.

\section{Appendix 1 Author table}

\begin{tabular}{|c|c|c|c|}
\hline Name & Location & Role & Contribution \\
\hline $\begin{array}{l}\text { Yuko Hara, } \\
\text { PhD }\end{array}$ & $\begin{array}{l}\text { Alzheimer's Drug } \\
\text { Discovery } \\
\text { Foundation }\end{array}$ & Author & $\begin{array}{l}\text { Drafted and revised the } \\
\text { manuscript for intellectual } \\
\text { content }\end{array}$ \\
\hline $\begin{array}{l}\text { Nicholas } \\
\text { McKeehan, } \\
\text { BS }\end{array}$ & $\begin{array}{l}\text { Alzheimer's Drug } \\
\text { Discovery } \\
\text { Foundation }\end{array}$ & Author & $\begin{array}{l}\text { Revised the manuscript for } \\
\text { intellectual content }\end{array}$ \\
\hline $\begin{array}{l}\text { Howard M } \\
\text { Fillit, MD }\end{array}$ & $\begin{array}{l}\text { Alzheimer's Drug } \\
\text { Discovery } \\
\text { Foundation }\end{array}$ & Author & $\begin{array}{l}\text { Drafted and revised the } \\
\text { manuscript for intellectual } \\
\text { content }\end{array}$ \\
\hline
\end{tabular}

\section{References}

1. Kennedy BK, Berger SL, Brunet A, et al. Geroscience: linking aging to chronic disease. Cell 2014;159:709-713.

2. Ricklefs RE, Scheuerlein A. Biological implications of the Weibull and Gompertz models of aging. J Gerontol A Biol Sci Med Sci 2002;57:B69-B76.

3. Anderson RM, Le Couteur DG. A long tradition in advancing aging biology and translational gerontology. J Gerontol A Biol Sci Med Sci 2018;73:271-272.

4. Gonneaud J, Arenaza-Urquijo EM, Mezenge F, et al. Increased florbetapir binding in the temporal neocortex from age 20 to 60 years. Neurology 2017;89:2438-2446.

5. Congdon EE, Sigurdsson EM. Tau-targeting therapies for Alzheimer disease. Nat Rev Neurol 2018;14:399-415.

6. Alzheimer's Drug Discovery Foundation 2017. Closing in on a Cure: $2017 \mathrm{Alz}$ heimer's Clinical Trials Report. Available at: alzdiscovery.org/research-and-grants/ clinical-trials-report/closing-in-on-a-cure-2017. Accessed July 26, 2018.

7. Shih HP, Zhang X, Aronov AM. Drug discovery effectiveness from the standpoint of therapeutic mechanisms and indications. Nat Rev Drug Discov 2018;17:19-33.

8. Franceschi C, Campisi J. Chronic inflammation (inflammaging) and its potential contribution to age-associated diseases. J Gerontol A Biol Sci Med Sci 2014; 69(suppl 1):S4-S9.

9. Corlier F, Hafzalla G, Faskowitz J, et al. Systemic inflammation as a predictor of brain aging: contributions of physical activity, metabolic risk, and genetic risk. Neuroimage 2018;172:118-129.
10. Warren KN, Beason-Held LL, Carlson O, et al. Elevated markers of inflammation are associated with longitudinal changes in brain function in older adults. J Gerontol A Biol Sci Med Sci 2018;73:770-778.

11. Marsland AL, Gianaros PJ, Kuan DC, Sheu LK, Krajina K, Manuck SB. Brain morphology links systemic inflammation to cognitive function in midlife adults. Brain Behav Immun 2015;48:195-204

12. Heneka MT, Carson MJ, El Khoury J, et al. Neuroinflammation in Alzheimer's disease. Lancet Neurol 2015;14:388-405.

13. Study evaluating safety, tolerability, and PK of multiple ascending doses of GC021109 in subjects with mild to moderate Alzheimer's disease. 2015. Available at: clinicaltrials. gov/ct2/show/study/NCT02386306. Accessed July 26, 2018.

14. GC 021109. Alzforum. Available at: alzforum.org/therapeutics/gc-021109. Accessed July 26, 2018.

15. Goldberg EL, Dixit VD. Drivers of age-related inflammation and strategies for healthspan extension. Immunol Rev 2015;265:63-74.

16. Fullerton JN, Gilroy DW. Resolution of inflammation: a new therapeutic frontier. Nat Rev Drug Discov 2016;15:551-567.

17. Serhan CN, Chiang N, Dalli J. The resolution code of acute inflammation: novel proresolving lipid mediators in resolution. Semin Immunol 2015;27:200-215.

18. Kirkland JL, Tchkonia T, Zhu Y, Niedernhofer LJ, Robbins PD. The clinical potential of senolytic drugs. J Am Geriatr Soc 2017;65:2297-2301.

19. Baker DJ, Petersen RC. Cellular senescence in brain aging and neurodegenerative diseases: evidence and perspectives. J Clin Invest 2018;128:1208-1216.

20. Biber K, Moller T, Boddeke E, Prinz M. Central nervous system myeloid cells as drug targets: current status and translational challenges. Nat Rev Drug Discov 2016, 15:110-124.

21. Brennan FH, Lee JD, Ruitenberg MJ, Woodruff TM. Therapeutic targeting of complement to modify disease course and improve outcomes in neurological conditions. Semin Immunol 2016;28:292-308.

22. Rubinsztein DC, Marino G, Kroemer G. Autophagy and aging. Cell 2011;146: 682-695.

23. Boyle PA, Yang J, Yu L, et al. Varied effects of age-related neuropathologies on the trajectory of late life cognitive decline. Brain 2017;140:804-812.

24. Turner RS. Impact of nilotinib on safety, biomarkers and clinical outcomes in mild to moderate Alzheimer's disease (AD). 2016. Available at: clinicaltrials.gov/ct2/show/ NCT02947893. Accessed July 26, 2018.

25. Lonskaya I, Hebron ML, Desforges NM, Schachter JB, Moussa CE. Nilotinib-induced autophagic changes increase endogenous parkin level and ubiquitination, leading to amyloid clearance. J Mol Med 2014;92:373-386.

26. Friedman LG, Qureshi YH, Yu WH. Promoting autophagic clearance: viable therapeutic targets in Alzheimer's disease. Neurotherapeutics 2015;12:94-108.

27. Harman D. Aging: a theory based on free radical and radiation chemistry. J Gerontol 1956; 11:298-300.

28. Jovanovic Z. Antioxidative defense mechanisms in the aging brain. Arch Biol Sci 2014 66:245-252.

29. Galasko DR, Peskind E, Clark CM, et al. Antioxidants for Alzheimer disease: a ran domized clinical trial with cerebrospinal fluid biomarker measures. Arch Neurol 2012; 69:836-841.

30. Sebastiao I, Candeias E, Santos MS, de Oliveira CR, Moreira PI, Duarte AI. Insulin as a bridge between type 2 diabetes and Alzheimer disease: how anti-diabetics could be a solution for dementia. Front Endocrinol 2014;5:110.

31. Zhang L, Zhang S, Maezawa I, et al. Modulation of mitochondrial complex I activity averts cognitive decline in multiple animal models of familial Alzheimer's Disease. EBioMedicine 2015;2:294-305.

32. Birk AV, Liu S, Soong Y, et al. The mitochondrial-targeted compound SS-31 reenergizes ischemic mitochondria by interacting with cardiolipin. J Am Soc Nephrol 2013;24:1250-1261.

33. Szeto HH. First-in-class cardiolipin-protective compound as a therapeutic agent to restore mitochondrial bioenergetics. Br J Pharmacol 2014;171:2029-2050.

34. Wu J, Zhang $\mathrm{M}, \mathrm{Li} \mathrm{H}$, et al. BDNF pathway is involved in the protective effects of SS 31 on isoflurane-induced cognitive deficits in aging mice. Behav Brain Res 2016;305: $115-121$.

35. Calkins MJ, Manczak M, Reddy PH. Mitochondria-targeted antioxidant SS31 prevents amyloid beta-induced mitochondrial abnormalities and synaptic degeneration in Alzheimer's disease. Pharmaceuticals 2012;5:1103-1119.

36. Gorelick PB, Scuteri A, Black SE, et al. Vascular contributions to cognitive impairment and dementia: a statement for healthcare professionals from the American Heart Association/American Stroke Association. Stroke 2011;42:2672-2713.

37. Toledo JB, Arnold SE, Raible K, et al. Contribution of cerebrovascular disease in autopsy confirmed neurodegenerative disease cases in the National Alzheimer's Coordinating Centre. Brain 2013;136:2697-2706.

38. Iadecola C. The pathobiology of vascular dementia. Neuron 2013;80:844-866

39. Bardehle S, Rafalski VA, Akassoglou K. Breaking boundaries-coagulation and fibrinolysis at the neurovascular interface. Front Cell Neurosci 2015;9:354.

40. Ryu JK, Petersen MA, Murray SG, et al. Blood coagulation protein fibrinogen promotes autoimmunity and demyelination via chemokine release and antigen presentation. Nat Commun 2015;6:8164.

41. Ryu JK, McLarnon JG. A leaky blood-brain barrier, fibrinogen infiltration and microglial reactivity in inflamed Alzheimer's disease brain. J Cell Mol Med 2009;13: 2911-2925.

42. Viggars AP, Wharton SB, Simpson JE, et al. Alterations in the blood brain barrier in ageing cerebral cortex in relationship to Alzheimer-type pathology: a study in the MRC-CFAS population neuropathology cohort. Neurosci Lett 2011;505:25-30. 
43. Ahn HJ, Chen ZL, Zamolodchikov D, Norris EH, Strickland S. Interactions of betaamyloid peptide with fibrinogen and coagulation factor XII may contribute to Alzheimer's disease. Curr Opin Hematol 2017;24:427-431.

44. van Oijen M, Witteman JC, Hofman A, Koudstaal PJ, Breteler MM. Fibrinogen is associated with an increased risk of Alzheimer disease and vascular dementia. Stroke 2005;36:2637-2641.

45. Grammas P, Martinez JM. Targeting thrombin: an inflammatory neurotoxin in Alzheimer's disease. J Alzheimers Dis 2014;42(suppl 4):S537-S544.

46. Brunet A, Berger SL. Epigenetics of aging and aging-related disease. J Gerontol A Biol Sci Med Sci 2014;69(suppl 1):S17-S20.

47. Delgado-Morales R, Agis-Balboa RC, Esteller M, Berdasco M. Epigenetic mechanisms during ageing and neurogenesis as novel therapeutic avenues in human brain disorders. Clin Epigenetics 2017;9:67.

48. Kuhrs S. Clinical trial to determine tolerable doses of vorinostat in patients with mild Alzheimer disease (VostatAD01). 2017. clinicaltrials.gov/ct2/show/NCT03056495. Accessed July 26, 2018.

49. Maes T, Molinero C, Antonijoan RM, et al. First-in-human phase I results show safety, tolerability and brain penetrance of ORY-2001, an epigenetic drug targeting LSD1 and MAO-B. Alzheimers Dement 2017;13:P1573-P1574.

50. Morrison JH, Baxter MG. The ageing cortical synapse: hallmarks and implications for cognitive decline. Nat Rev Neurosci 2012;13:240-250.

51. Scheff SW, Price DA, Schmitt FA, Mufson EJ. Hippocampal synaptic loss in early Alzheimer's disease and mild cognitive impairment. Neurobiol Aging 2006;27:1372-1384.

52. Simmons DA, Knowles JK, Belichenko NP, et al. A small molecule p75NTR ligand, LM11A-31, reverses cholinergic neurite dystrophy in Alzheimer's disease mouse models with mid- to late-stage disease progression. PLoS One 2014;9: e102136.

53. Cuadrado-Tejedor M, Ricobaraza AL, Torrijo R, Franco R, Garcia-Osta A. Phenylbutyrate is a multifaceted drug that exerts neuroprotective effects and reverses the Alzheimer s disease-like phenotype of a commonly used mouse model. Curr Pharm Des 2013;19:5076-5084.

54. Ricobaraza A, Cuadrado-Tejedor M, Garcia-Osta A. Long-term phenylbutyrate administration prevents memory deficits in Tg2576 mice by decreasing Abeta. Front Biosci 2011;3:1375-1384.

55. Ricobaraza A, Cuadrado-Tejedor M, Marco S, Perez-Otano I, Garcia-Osta A. Phenylbutyrate rescues dendritic spine loss associated with memory deficits in a mouse model of Alzheimer disease. Hippocampus 2012;22:1040-1050.

56. Rodrigues CM, Sola S, Brito MA, Brondino CD, Brites D, Moura JJ. Amyloid betapeptide disrupts mitochondrial membrane lipid and protein structure: protective role of tauroursodeoxycholate. Biochem Biophys Res Commun 2001;281:468-474.

57. Dionisio PA, Amaral JD, Ribeiro MF, Lo AC, D’Hooge R, Rodrigues CM. Amyloidbeta pathology is attenuated by tauroursodeoxycholic acid treatment in APP/PS1 mice after disease onset. Neurobiol Aging 2015;36:228-240.

58. Nunes AF, Amaral JD, Lo AC, et al. TUDCA, a bile acid, attenuates amyloid precursor protein processing and amyloid-beta deposition in APP/PS1 mice. Mol Neurobiol 2012;45:440-454.

59. Frank LK. Gerontology. J Gerontol 1946;1:1-12.

60. Banfi C, Baetta R, Gianazza E, Tremoli E. Technological advances and proteomic applications in drug discovery and target deconvolution: identification of the pleiotropic effects of statins. Drug Discov Today 2017;22:848-869.

\section{Neurology ${ }^{\circledast}$ Online CME Program}

Earn CME while reading Neurology. This program is available only to online Neurology subscribers. Read the articles marked CME, go to Neurology.org, and click on CME. This will provide all of the information necessary to get started. The American Academy of Neurology (AAN) is accredited by the Accreditation Council for Continuing Medical Education (ACCME) to sponsor continuing medical education for physicians. Neurology is planned and produced in accordance with the ACCME Essentials. For more information, contact AAN Member Services at 800-879-1960.

\section{Sign Up for the AAN's Axon Registry}

The AAN encourages its US members to show their interest in participating in the Axon Registry ${ }^{\circledR}$ by signing up today.

Use the Axon Registry to:

- Simplify reporting requirements under MACRA’s Quality Payment Program and avoid penalties while reducing your administrative burden

- Meet your MOC Part IV requirements and waive up to eight credits of Part II Self-Assessment

- Choose from 22 AAN neurology-specific quality measures that fit your practice

- Use data to understand your practice and identify where improvements can be made to patient care

- Manage your patients at a population level; look at a specific group of patients based on conditions, risk factors, demographics or outcome

- Demonstrate your value to payers when negotiating reimbursement

- Enjoy multi-year, fee-free access when you sign the agreements and integrate your EHR with the registry

Learn more at AAN.com/view/Axon and send your questions to registry@aan.com. 


\section{Neurology}

\section{Translating the biology of aging into novel therapeutics for Alzheimer disease \\ Yuko Hara, Nicholas McKeehan and Howard M. Fillit}

Neurology 2019;92;84-93 Published Online before print December 7, 2018

DOI 10.1212/WNL.0000000000006745

This information is current as of December 7, 2018

\section{Updated Information \& Services \\ Supplementary Material \\ References \\ Subspecialty Collections}

\section{Permissions \& Licensing}

Reprints including high resolution figures, can be found at: http://n.neurology.org/content/92/2/84.full

Supplementary material can be found at: http://n.neurology.org/content/suppl/2019/09/01/WNL.0000000000006 745.DC1

This article cites 55 articles, 4 of which you can access for free at: http://n.neurology.org/content/92/2/84.full\#ref-list-1

This article, along with others on similar topics, appears in the following collection(s):

All Cognitive Disorders/Dementia

http://n.neurology.org/cgi/collection/all_cognitive_disorders_dementia Alzheimer's disease

http://n.neurology.org/cgi/collection/alzheimers_disease

Cognitive aging

http://n.neurology.org/cgi/collection/cognitive_aging

MCI (mild cognitive impairment)

http://n.neurology.org/cgi/collection/mci_mild_cognitive_impairment

Information about reproducing this article in parts (figures,tables) or in its entirety can be found online at:

http://www.neurology.org/about/about_the_journal\#permissions

Information about ordering reprints can be found online:

http://n.neurology.org/subscribers/advertise

Neurology ${ }^{\circledR}$ is the official journal of the American Academy of Neurology. Published continuously since 1951, it is now a weekly with 48 issues per year. Copyright Copyright ( 2018 The Author(s). Published by Wolters Kluwer Health, Inc. on behalf of the American Academy of Neurology.. All rights reserved. Print ISSN: 0028-3878. Online ISSN: 1526-632X.

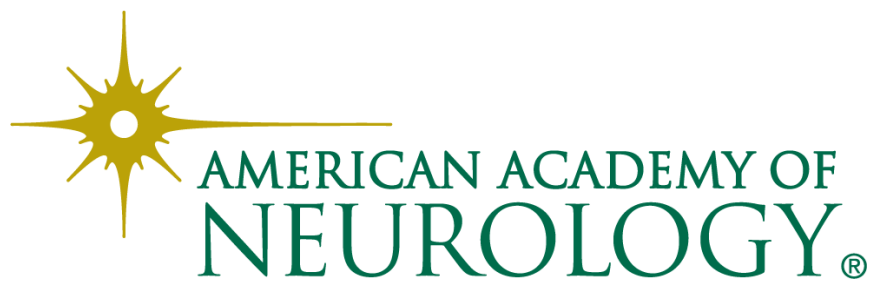

